\title{
Blessed Michael Sopocko: Pedagogue and Educator
}

One of the fundamental and important dimensions of Fr. Michael Sopocko's life and work was his pedagogical activity and creativity. Fr. Sopocko taught as a lecturer in the seminary for the majority of his life and at the university for a number of years. He left a rich legacy of research and academic work in the form of popular and journal publications. Up to now, some minor studies have discussed Fr. Sopocko's pedagogical achievements. This study contributes to a growing and important body of work by presenting Fr. Sopocko's academic path, didactic work, and academic and written creativity and achievements as a pedagogue and educator

Key words: Fr. Michael Sopocko, Christian education, pedagogics.

\section{Introduction}

Fr. Sopocko is best known for his connection with the apostolate of Divine Mercy. The key to understanding his personality and mission is the fact that he was a servant of mercy and dedicated all of his energy to promoting Divine Mercy. For this reason, his contribution to the development of devotion to Divine Mercy has been studied extensively. ${ }^{1}$ In many of their studies, however, scholars have not always remembered that one of the most fundamental and important aspects of Fr. Sopocko's life and work was his pedagogical activity and

See H. Ciereszko, Droga świętości ks. Michała Sopoćki, Cracow 2002; H. Ciereszko, Życie i działalność Księdza Michała Sopoćki (1888-1975). Pełna biografia Apostoła Miłosierdzia Bożego, Cracow 2006. 
Bl. Michael Sopocko

creativity. Fr. Sopocko taught and lectured at the seminary throughout most of his life and at the university for part of his life. Consequently, he left behind a rich academic legacy in the form of publications as well as popular writings and journal publications. Up to now, some minor studies have discussed Fr. Sopocko's pedagogical achievements. ${ }^{2}$ This study, which touches only the surface of this topic, contributes to the growing and important body of work that presents the academic path, didactic work, and academic and written creativity of Fr. Sopocko as a pedagogue and educator.

\section{Pedagogical Preparation and Activity}

From a very young age, Fr. Michael Sopocko demonstrated a clear desire to acquire knowledge. Intellectually gifted, he was like a sponge that absorbed knowledge even when his external circumstances often made it difficult for him to have access to it. The further Fr. Sopocko went in his education, the more he saw how valuable and useful learning is in life.

Fr. Sopocko received his initial education in difficult circumstances. In his Memoirs, he pointed out that "scientific learning was, among other things, one of the main tasks of my life. However, because of my duties, I could not devote myself solely to [education] [...] whenever I could, I took advantage of every occasion to continue studying." 3 Fr. Sopocko went on to say that he took preliminary steps in his education-namely, he studied English and French privately and also refreshed his knowledge of German, which he had learned in school.

Fr. Sopocko began acquiring educational skills very early in life. When he was barely 19 years old, he began teaching at school because the circumstances of his life forced him to do so. After graduating from the municipal school in Oszmiana in 1906, Michael was had to cease

See S. Strzelecki, Wkład księdza Michała Sopoćki w formację duchowieństwa, Bialystok 1983; D. Steć, Wychowawca, aby pociagat, musibyćautentyczny, "Czas Miłosierdzia”, 162(2003) no. 10, pg. 9; A. Skreczko, Wychowanie chrześcijańskie w ujęciu Ks. Michała Sopoćki, "Rocznik Teologii Katolickiej” 2005, vol. IV, pgs. 59-98; H. Ciereszko, Ksiadz Michat Sopoćko profesor, wychowawca i ojciec duchowy alumnów i kapłanów, Bialystok 2008; H. Ciereszko, Działalność naukowa i dydaktyczna Księdza Michała Sopoćki, "Studia Teologiczne. Bialystok - Drohiczyn - Lomza" 26(2008), pgs. 7-56; E. Młyńska, Ksiądz Michat Sopoćko jako wychowawca, "Katecheta" 2008, no. 11, pgs. 67-71; M. Olszewski, Ksiadz Michat Sopoćko jako profesor wykładowca w Wilnie i w Biatymstoku, "Rocznik Teologii Katolickiej”, 2016, vol. XV/1, pgs. 181-200. 
further studies because his parents' financial and material situation had deteriorated. In February 1907, he was offered a teaching position at a newly established Polish school associated with the local parish in Bl. Michael Sopocko Zabrzez. ${ }^{4}$ Michael Sopocko's work at the school suited him very well. In this way, from the beginning, Fr. Sopocko was interested in teaching, which spurred him to acquire the methodological skills necessary to properly guide and educate others.

While teaching, Michael sought to improve his knowledge of proper Polish by reading classical Polish literature, particularly the works of Adam Mickiewicz. During this time, he discovered the beauty and richness of Polish culture, which had been immortalized in the country's national literature. Fr. Sopocko's reading undoubtedly shaped his personality, taught him about patriotism, and convinced him to work on developing his religious and moral values.

The further Michael went in his education, the more he saw how useful knowledge was in life. For this reason, he continued his education after he graduated from the seminary in Vilnius in 1914 and entered into pastoral ministry. More specifically, at the end of September 1918 Fr. Sopocko went to Warsaw where he pursued higher theological studies in moral theology at the University of Warsaw's Faculty of Theology and attended lectures on law and philosophy. In 1923, he obtained his Master's degree in Theology. ${ }^{5}$

After obtaining his Master's in Theology, Fr. Sopocko decided to continue his studies in the University of Warsaw's Department of Moral Theology and prepare his doctoral thesis under the direction of Professor Franciszek Jehliczka. On March 1, 1926, Fr. Sopocko successfully defended his thesis on the ethics of the family and civil legislation. ${ }^{6}$ In his thesis, Fr. Sopocko demonstrated the extent to which Polish civil legislation was consistent with the principles of Christian morality, and he pointed out the need to create civil laws that were in accordance with the natural law revealed in matters pertaining to family ethics. ${ }^{7}$

In addition to studying theology, Fr. Sopocko spent two years (19221924) studying pedagogy at the State Pedagogical Institute. At the end of his studies, he successfully passed his exam before the State Examination Commission and received a good score. In addition, as

$4 \quad$ M. Sopoćko, Wspomnienia z przeszłości (Życiorys napisany własnymi stowami), WKAB 13(1985) no. 2, pg. 104. chive of the Archdiocese of Bialystok (hereafter abbreviated as: AAB), IV 14. 
Bl. Michael Sopocko

part of the requirements to obtain his diploma, he submitted a paper entitled Alcoholism Among School-Aged Youth, which received very high marks. Fr. Sopocko's thesis was the result of the research that he had carried out among youth in primary and secondary schools where, as the title of his thesis suggests, he studied the problem of the influence of alcohol on adolescent development. The results of his study showed alcohol's destructive effects on young people and made others aware of the risks and actual harm that alcohol has on the young. The reviewers of Fr. Sopocko's work appreciated its quality and relevance, and efforts were made to publish it. ${ }^{8}$ Once he completed his pedagogical studies, Fr. Sopocko obtained his master's degree in pedagogy and was qualified to teach pedagogical subjects in high schools that provide general education and at teaching seminars. ${ }^{9}$

Michael Sopocko expanded his knowledge on issues related to pedagogy by engaging in didactic work among teachers. In fact, the Board of Trustees for the School District of Vilnius hired him for many years to give lectures in psychology, pedagogy, teaching methodology, and especially religion to teachers. ${ }^{10}$ With a sense of understanding and responsibility, Fr. Sopocko entered into these educational activities that were indispensible in Polish society at the time. The National Polish Association of Christian Teachers also invited Fr. Sopocko to provide similar lectures to public school teachers through the Higher Level Course in Philosophy and Mathematics during the 1925-26 and 1926-27 school years. ${ }^{11}$

Fr. Sopocko engaged in didactic activities even during his pastoral ministry in the army. At that time, he provided soldiers and officers with religious and ethical training, during which he aroused in them a spirit of patriotism and helped to awaken in and transmit to them civic attitudes. His talks, which were published in 1922 under the title "Duties to One's Homeland," serve as a model for this type of education and reveal Fr. Sopocko's great concern for the soldiers' morale as well as for their religious, moral, and patriotic education. Fr. Sopocko himself also exemplified the values that he taught. ${ }^{12}$

M. Sopoćko, Wspomnienia..., Chapter III, pg. 44.

Copy of Fr. Sopocko's Diploma, AAB, XI 12.

Letter from the Vilnius School District: Entrusting Teaching to the State. Higher Course for Teachers in Vilnius 1926/27, date September 15, 1926, N.I-20691/26, duplicate, AAB, XII 5.

Letter from the Vilnius District Branch of the National Association of Christian Teachers written in Poland on June 3, 1928 (duplicate), AAB, XI 1.

Por. H. Ciereszko, Droga świętości ks. Michała Sopoćki, Cracow 2002, pg. 32. 
From 1928 onward, Fr. Sopocko worked at the Seminary in Vilnius where the professors' primary task was teaching. Fr. Sopocko taught various subjects both in Vilnius and in Bialystok (after the war), includBl. Michael Sopocko ing: pastoral theology, catechetics, pedagogy, Latin, and even Russian. ${ }^{13}$

After he was released from his role as spiritual father of the Seminary in 1932, Fr. Sopocko lived next to the convent of the Visitation sisters for two years while he collected and compiled materials and wrote his dissertation entitled The Aim, Subject, and Object of Spiritual Education According to Mikolaj Leczycki. In order to complete his habilitation, he was obliged to work as a lecturer at the Seminary and at the University of Warsaw's Faculty of Theology-a position that he held from 1927 onward. Initially, he was employed as a lecturer in the history of philosophy, but in 1928, he was appointed Assistant Professor in the Department of Pastoral Theology.

Fr. Sopocko received his habilitation from the University of Warsaw and was granted the title of Senior Lecturer of Pastoral Theology in 1934. Fr. Sopocko continued further studies on the Leczycki's scientific legacy and compiled all of Leczycki's research on educating children into a four-volume work entitled Mikolaj Leczycki on Spiritual Education, which was published in Vilnius in 1935. This work gave Fr. Sopocko sufficient grounds to apply for the title of Full Professor and Chair of the Department of Theology in the University of Warsaw's Faculty of Theology. Unfortunately, although Fr. Sopocko was widely thought to be the most competent candidate, he was not promoted to the position of professor due most likely to the fact that the department lacked the necessary financial means.

In addition to his scientific work, Fr. Sopocko was continually responsible for lecturing once he became involved at the university. In addition to the lectures he gave on the history of philosophy, he also taught pastoral theology, which was the main area had studied and in which he was interested. In this field, he gave lectures and led seminars on homiletics, catechetics, and pedagogy. He taught these classes until the university and seminary closed during World War II.

In his teaching, Fr. Sopocko greatly strove to provide students with practical preparation they would need for their future pastoral work. ${ }^{14}$

13 Por. S. Strzelecki, Ksiadz Michat Sopoćko jakiego znałem i pamiętam, Warsaw 2004.

14 Archbishop Edward Ozorowski said the following about Fr. Sopocko as his educator: "I also remember the practical advice that Fr. Sopocko gave to us. For example, he told us to walk upright, speak slowly and clearly, wash your body with cold water to the waist every morning, read literature to increase your vocabulary [...] He taught us prayers in Russian and required us to memorize 
Bl. Michael Sopocko

His teaching aimed at synthesizing knowledge and practical skills. When teaching homiletics to students, for example, he would provide exercises on diction, how to elaborate properly on a given topic, and how to give homilies. He prepared and taught catechesis in schools with the same solicitude with which he prepared his academic work. He required that his students take catechesis classes taught only by qualified catechists so that they would learn the proper way to teach classes.

When giving lectures on pedagogy, Fr. Sopocko always prepared a script, just as he did when lecturing on other subjects. ${ }^{15}$ The script was then duplicated on the copy machine in the Research Assistance Department of the Circle of Theologians at the Stefan Batory University. Because suitable textbooks were not available at that time, and the scripts that Fr. Sopocko prepared for the subjects that he taught made it easier for the students to acquire and retain knowledge, these scripts were one of Fr. Sopocko's achievements that expressed his great concern for his students.

In addition to teaching, Fr. Sopocko collaborated with Fr. Jozef Wojtukiewicz to publish the Vilnius monthly "Toward the Summit," which was dedicated to issues on pedagogy and education.

Keeping in mind Fr. Sopocko's competent preparation of priests through his work as a pedagogue and his theoretical and practical involvement in this area, the following section will analyze his pedagogical creativity.

\section{Pedagogical Creativity and Views ${ }^{16}$}

In his pedagogical work and views, Fr. Michael Sopocko studied, explored, and discussed the problem of education in light of dogmatic,

Krylova's fairytales. He explained that we should move to the East and proclaim the Gospel [to the people] there." H. Ciereszko, Ksiadz Michat Sopoćko profesor, wychowawca i ojciec duchowy alumnów i kapłanów, Bialystok 2008, pg. 13.

His script contained a clear and concise lecture on theology as well as knowledge on pedagogy that the seminarians particularly needed. He discussed introductory concepts (pedagogical ideas, sources, types, and the aims of education), general elements of education, and elements of education that are implemented consciously, types of education, a short review of the history of education in schools, education in the east, Greece, Rome, Middle Ages, the Enlightenment, and the $19^{\text {th }}$ and $20^{\text {th }}$ centuries), contemporary trends in education, and the means of (physical, intellectual, and moral) education.

16 The following studies contain more detailed overviews of Fr. Sopocko's teachings on Christian education: H. Ciereszko, Działalność naukowa i dydaktyczna Księdza Michała Sopoćki, "Studia Teologiczne. Bialystok-Drohiczyn-Lomza" 
liturgical, pastoral, and ascetic aspects. He provided a traditional education that was based on the Holy Bible. He liked the concept of education that Pope Pius XI presented in his encyclical Divini Illius Bl. Michael Sopock0 Magistri. Fr. Sopocko discussed some issues more precisely and in depth.

As mentioned above, in his postdoctoral thesis, Fr. Sopocko examined the concept of spiritual education as understood by Mikolaj Leczycki (1574-1653), a Polish Jesuit, theologian, and educator. Fr. Sopocko's personal interest in pedagogy as well as his practical need to have in-depth knowledge of pedagogy in his work with priests and educators inclined him to pursue this topic. In addition, he thought that gathering and sharing Leczycki's views and teaching on education would provide new and useful inspiration for contemporary educational activities in general and on the spiritual level in particular.

Fr. Sopocko's academic work on Leczycki's concept of education touched upon theology and pedagogy. Among his works, however, there are those that are strictly pedagogical. For example, Fr. Sopocko wrote an article based on a lecture on education that he had given at the Catholic Studium in Vilnius in 1936. In this article, he specifically discussed Polish and Catholic ideas and education systems. ${ }^{17}$ Notably, Fr. Sopocko published another article on pedagogy that was based on a lecture that he had given at the $8^{\text {th }}$ Convention for the Association of Theological Institutes in Czestochowa in 1937. This article discussed the relationship between nature and the supernatural, the will and grace, and natural and supernatural means in the education. ${ }^{18}$ Another one of Fr. Sopocko's important pedagogical studies is entitled "Religious Learning and Education in School."19

Fr. Michael Sopocko believed that scholars and educators had to sufficiently present and explain the concept, purpose, means, and methods of Christian education. ${ }^{20} \mathrm{He}$ thought that this concept depends on one's view of the world and especially on human nature.

26(2008),pgs. 7-56; A. Skreczko, Wychowanie chrześcijańskie wujęciu Ks. Michała Sopoćki, "Rocznik Teologii Katolickiej" 2005, vol. IV, pgs. 59-98.

See M. Sopoćko, Polskie i katolickie ideaty $i$ systemy wychowawcze, Poznan 1936.

Fr. Sopocko largely refers to the results of M. Leczycki's research on pedagogical ideas and how they relate to contemporary educational issues. Fr. Sopocko pointed out that, if the naturalistic trend in education becomes stronger, then religion will be removed from education in schools and religious practices will be removed from raising children. Vilnius 1939.

See M. Sopoćko, Miłosierdzie Boga w dziełach Jego, Paris 1967, Vol. 4, pg. 95. 
Bl. Michael Sopocko

The basis of Fr. Sopocko's education system are the truths revealed by God. Needless to say, some of these truths are only loosely or incidentally associated with education. Like Pope Pius XI, Fr. Sopocko based his concept of education on three dogmas: creation, redemption, and sanctification. In addition, Fr. Sopocko further based his concept of Christian education on the dogma of human creation, while the dogma of redemption served as the basis for his reflection on the topic of education, and the truth about sanctification through grace is the basis of his search for the purpose of Christian education.

According to Fr. Sopocko, "among the many issues concerning Christian education, the most pressing is the question of the relationship between nature and the supernatural, the will and grace, as well as natural and supernatural means." ${ }^{21}$ Fr. Sopocko, therefore, rejected all pedagogical trends that do not follow the assumptions of Catholic teaching. According to Fr. Sopocko, these trends depended on how one views human nature, and he narrowed these views to the following three categories: extreme individualism, sociologism, and materialism..$^{22}$ Among the most extreme pedagogical approaches, the Catholic approach can be found somewhere in the middle. In his reflections, Fr. Sopocko constantly returned to what is important in Christian educational thought—namely, the relationship between man and God, meaning religion.

Fr. Sopocko was perfectly aware of the fact that the foundations of Christian education are permanent, unchanging, and linked to the essence and aim of all of education. Fr. Sopocko thought that the framework of pedagogical science built on this foundation should take into account social and economic changes. The Fathers of the Second Vatican Council were of the same belief, which they expressed in the Delcaration on Christian Education: Gravissimum Educationis as well as The Pastoral Constitution on the Church in the Modern World: Gadium et Spes.

Fr. Sopocko believed that the Church's teaching on original sin and its consequences on human nature were very important in both theory and practice. For this reason, when explaining the concept of education, he took into account this view of human nature: "Christian teaching tells us that nature is not evil, as sociologists would have us believe, and that it also is not wholly good, as the proponents of

\footnotetext{
$21 \quad$ M. Sopoćko, Przyrodzone i nadprzyrodzone czynniki wychowania, Cracow 1937, pg. 1.

22 M. Sopoćko, Miłosierdzie Boże..., pg. 95.
} 
individual naturalism maintain. Rather [nature] is contaminated by original sin." 23

According to Fr. Sopocko, the main aim of education is the perfecBl. Michael Sopocko tion of the human person according to the measure of God himself. Christ himself commanded this: "Be perfect as your heavenly Father is perfect" (Mt 5:48). Following Pope Pius XI's concept of education, Fr. Sopocko stated: "The main distant goal [of education] is connected with the goal of life in general, and the main immediate goal [of education] is associated with the purpose of human life."24 Fr. Sopocko believed that the person who does not have a clear idea of the purpose of human life cannot have a clear understanding of the primary purpose of education.

Fr. Sopocko knew that, in the education process, the educator must first answer the question: "What is man's purpose?" The purpose of education will spontaneously be made manifest once one has determined the purpose of life, which Catholicism clearly defines. The main distant purpose of education corresponds to the ultimate goal of man, which is eternal happiness that comes through full participation in the life of the Holy Trinity.

The educational process requires constant cooperation on the part of the educator and the one being educated. Fr. Sopocko believed that the educator's attitude during the education process is both activepassive, while the attitude of the one being educated is passive-active. This results not only from the aim of education, but above all else from self-education. The one being educated should first accept the educator's (passive party) instructions, and then follow these instructions in his own life through a concrete action (active party). ${ }^{25}$ Since man is a complex material and spiritual being, and since supernatural life depends on nature, both factors play an equal role in education.

In man's earthly life, opposing forces constantly clash with each other. Education and, strictly speaking, internal harmony, which is the aim of Christian education, counterbalance these oppositions. Fr. Sopocko accepted these opposites as the foundation of Christian education.

Fr. Sopocko did not precisely specify the attitude of a "true Christian," but what he understood as this attitude can be deduced based

\footnotetext{
$23 \quad$ M. Sopoćko, Pedagogika, Vilnius 1933, typescript, pg. 5.

24 M. Sopoćko, Miłosierdzie Boże..., pg. 101. See M. Sopoćko, Cel, podmiot i przedmiot wychowania, Vilnius 1933, pg. 6. 
Bl. Michael Sopocko on his teachings on Christian education. ${ }^{26} \mathrm{~A}$ true Christian who has a supernatural character is not hostile toward social and civic life and is a good citizen. ${ }^{27}$ This is why Fr. Sopocko discussed a Christian's duties as a good citizen ${ }^{28}$ and believed that learning and fulfilling these duties shapes man's character.

According to Fr. Sopocko, only God is an educator in the strict sense of the word, because only He can form an excellent personality ${ }^{29}$ and only He calls man into existence. Analogously, parents are the primary educators of their children "because they provide their children with the foundation upon which the creative power of the Most High God [can build]." 30 The family, therefore, has the greatest natural right to educate children.

The family, which was called into being by God from nature for its own purpose, meaning to bring forth children and raise them, has the primacy in educating children. "In the hearth of family life-in its unwritten and clear legislation-the developing person is formed socially, individually, and morally." 31 The Church complements and assists the family in educating individuals on the supernatural level. On the natural and temporal level, the state complements the family in the education process..$^{32}$

Education is a well thought-out and organized human activity. Fr. Sopocko makes a distinction between the subject and the object and demonstrates that both are important elements in education (as in every human activity). Fr. Sopocko's concept was nothing new; rather, it was a continuation of Mikolaj Leczycki's pedagogical thought on

$26 \quad$ "Christian education focuses on the central idea of an absolute Good of all values and it upholds the Person of the Most Merciful Redeemer as the primary model. Because Christ's life is the most perfect model and idea of virtues and holiness, the more our life resembles His life and the more we imitate Him, then the more [we] will become perfect." M. Sopoćko, Mitosierdzie Boże..., pg. 126. Fr. Sopocko discusses these issues in particular in Obowiazki względem Ojczyzny, Warsaw 1922 and O obowiazkach społecznych, Vilnius 1931.

O obowiązkach społecznych, pg. III-IV.

Fr. Sopocko took this thought from St. Thomas Aquinas who claimed that God is the only educator in the strict sense of the word. See St. Thomas Aquinas, Summa Teologiae. I. q. CXVII, s. 1.; Quest. disp. q. XI, a. 1.

$30 \quad$ M. Sopoćko, Miłosierdzie Boże...,pg. 109; see Ibid, Autorytet w rodzinie a wolność dziecka, "Ku szczytom,” Vilnius 1939, pg. 128.

M. Sopoćko, Pedagogika..., pgs. 31-32.

32 "God gives the state the right to educate not based on fatherhood, which is present in a family and the Church, but based on the authority it has to promote the communal temporal good.” M. Sopoćko, Pedagogika..., pg. 37. 
and Pope Pius XI's understanding of education. ${ }^{33}$ Fr. Sopocko believed that education should result from the cooperation between the subject and the pedagogical object, such that it should gradually become selfBl. Michael Sopocko education that lasts a lifetime. ${ }^{34}$

In his writings, Fr. Sopocko points out that the qualities of a good educator are purely natural. Such qualities as piety and mortification, among others, are, in a sense, the superstructure of the educator's natural qualities. A good educator is above all a good person whose exemplary fulfillment of his professional, social, and religious duties serves as a daily example to youth.

A good educator should have an individual approach to the person he is teaching and adjust his attitude depending on his pupil's age and level of development. ${ }^{35}$ Education should also involve the whole person.

Fr. Sopocko contrasted his teaching, which emphasizes that rational and free man is the subject of a Christian education and that man is an integral whole made up of body and soul, with erroneous pedagogical directives that belittle or considers the object of education in a manner that is too one-sided. ${ }^{36}$

Rejecting erroneous pedagogical trends, Fr. Sopocko indicated that the only solution is to situate Christian pedagogy between these extreme trends. According to Fr. Sopocko, the Catholic approach to pedagogy, on the one hand, combines individualist and social naturalism

Mikolaj Leczycki was born in 1574 . He was a member of the Society of Jesus. As a Catholic theologian, he followed the general teachings of the Catholic Church and the great theologians, particularly St. Thomas Aquinas, in his views on education. At the same time, however, Leczycki expressed his own rather bold and innovative thoughts on education, of which his superiors did not always approve. Fr. Sopocko drew from many of Leczycki's valuable ideas regarding education. He knew Leczycki's work very well, since he wrote his habilitation dissertation on this topic. See M. Sopocko, Mikołaj Łęczycki o wychowaniu duchowym, Vilnius 1935, pg. 1-25.

"In Christian education, the educator must gradually help the student to become independent-to instill him the ability to self-educate not only by giving him instructions, but also by preparing in his soul the foundation to independently resist wrong incentive and to follow the ideal." M. Sopoćko, Miłosierdzie Boże..., pg. 123.

Ibid, pg. 113.

36 Fr. Sopocko rejected naturalism as well as pedagogical liberalism, which advocates complete human autonomy as the essence of a natural good that is not subject to any form of restraint. See Sopoćko, Mitosierdzie Boże..., pg. 95. 
Bl. Michael Sopocko

and, on the other hand, falls somewhere in between extreme naturalism and Protestant supernaturalism. ${ }^{37}$

Like any other human activity, education takes place through the use of the appropriate means that lead to its goal. Based on a particular view of human nature, Christian education's resources are divided into the natural and supernatural. ${ }^{38}$ Fr. Sopocko ranks the environment in which pupils live first among the many means of education. He included in the environment those people and things that surround and unconsciously and consciously affect the pupil. ${ }^{39}$ Not only the environments that are strictly and consciously educative (i.e., the pedagogical environment) influence human development, so too do the physical, biological, cultural, and social environments in which one lives. Fr. Sopocko included the family, the Church, and the state among the environments that are strictly pedagogical.

Fr. Sopocko asserted that some supernatural means evoke grace thanks to man's efforts, while other supernatural means cause it directly. ${ }^{40}$ For Sopocko specified that these supernatural means are connected with natural means because they require active human involvement such as prayer, ejaculatory prayers, and retreats. ${ }^{41}$ Although the means of education that Fr. Sopocko pointed out have been known for a long time, Fr. Sopocko's insightfully related these means with the immediate and distant goals of Christian education. In addition, he greatly emphasized the personal effort involved in education and cooperation with grace, which is the basis of self-education. While he felt that the natural means of education were very important, he also emphasized that man's education is possible only with the help and influence of grace, which supernatural means participate in and increase.

Fr. Sopocko included the liturgy (as well as the liturgical year), Holy Mass, the sacraments, sacramentals, and other acts of public worship prescribed by the Church as official methods of Christian education.

See M. Sopoćko, Przyrodzone i nadprzyrodzone czynniki...,, pg. 4. According to supernaturalists, human nature was essentially contaminated by original sin to such a degree that only a contaminated intellect and perverse will remain. In this way, everything that is in the will is evil, and everything that is in the human intellect is erroneous.

Ibid, pg. 6.

M. Sopoćko, Mitosierdzie Boże..., pg. 127.

Ibid, pg. 138.

Ibid, pgs. 138-139: "Prayer involves and harmonizes all interior human powers and complements all means of education [...] it raises the soul to heaven, unites it with the Creator, and by means of this leads to the main aim of education." 
He believed, therefore, that every Christian should respect liturgical prescriptions and consider them one of the most important methods of Christian education. ${ }^{42}$

Fr. Sopocko's teaching accords with the teaching of the Second Vatican Council with regard to the object of education and it purpose. Fr. Sopocko defined the subject of education very broadly: "All people, regardless of their race, state [in life], and age have dignity and, therefore, have the inviolable right to an education." ${ }^{33} \mathrm{He}$ expanded the subject of education not only to include the whole person, but also all people from every time.

When summarizing everything that has been said about Fr. Michael Sopocko as a pedagogue and his views on education, it is important to note that his teaching is remarkably humanistic. As a worldview, humanism is manifested in pedagogy according to three approaches: sociological, evolutionary, and Christian. The latter preaches the liberation of man from his own passions, meaning man's need to achieve inner harmony. The dogma of redemption is the source of Christian humanism. However, because Fr. Sopocko broaded the object of education to include the whole person, the dogmas of creation and sanctification are also the basis of his considerations. Starting from the premise that human nature was not violated by sin in its very essence, Fr. Sopocko defined Christian education as a way to strive for an interior harmonization of the lower and higher faculties. Fr. Sopocko presents Jesus Christ, the Way, the Truth, and the Life (John 14:6) as the model for all educators and students.

\section{Conclusion}

This article briefly presents Fr. Sopocko's pedagogical activity and creativity. Pedagogy was an important field in Fr. Sopocko's life and an area of research for which he had a particular passion that began in his youth and lasted for years. Fr. Sopocko took his first steps as an educator before he entered the seminary when he began teaching at the parish school in Zabrzez. His studies at the Institute of Pedagogy provided him with expert training, which he made use of when teaching in Vilnius and later at the university and in the seminary where

\footnotetext{
42 Ibid, pg. 164: "In addition to official methods, there are also private methods, some of which the Church approves and others of which She tolerates. Official methods arise from private methods." 
Bl. Michael Sopocko

he taught pedagogy. Fr. Sopocko's work, understanding attitude, and respect for others, made him a good educator.

Fr. Sopocko's work on M. Leczycki's concept of education takes into consideration both theology and pedagogy. Although Fr. Sopocko did not write very much on pedagogy alone, that which remains of his writings on the practical and theological aspects of Christian education distinguish him among well-known Polish pedagogues. In a certain way, his views on pedagogy are a precursor to the thoughts on education expressed in the documents of the Second Vatican Council. While upholding the value of traditional learning, Fr. Sopocko ideas were innovative and ahead of his time. He realized that the main assumptions of Catholic pedagogical thought are permanent and unchanging, even if it is necessary to take into account the living conditions and spirit of the times when creating an educational system.

\section{BŁOGOSŁAWIONY MICHAŁ SOPOĆKO: PEDAGOG I WYCHOWAWCA}

Jednym z podstawowych i ważnych wymiarów życia i pracy ks. Michała Sopoćki była jego działalność i twórczość pedagogiczna. Przez większość swego życia prowadził dydaktykę, jako wykładowca w seminarium duchownym i przez szereg lat także na uniwersytecie. Pozostawił bogatą spuściznę naukową w postaci publikacji, a także dorobek pisarski o charakterze popularyzatorskim i publicystycznym. Dotychczas pojawiły się pomniejsze opracowania ukazujące jego dorobek w dziedzinie pedagogicznej. Niniejsze opracowanie przedstawia naukową drogę, pracę dydaktyczną oraz twórczość naukową i piśmienniczą ks. Sopoćki, jako pedagoga i wychowawcy. Jest to zaledwie przyczynek w tym ważnym temacie.

Słowa kluczowe: ks. Michał Sopoćko, wychowanie chrześcijańskie, pedagogika.

\section{Bibliography:}

1. Ciereszko H., Droga świętości ks. Michała Sopoćki, Cracow 2002

2. Ciereszko H., Działalność naukowa i dydaktyczna Księdza Michała Sopoćki, "Studia Teologiczne. Bialystok-Drohiczyn-Lomza" 26(2008), pgs. 7-56.

3. Ciereszko H., Ksiadz Michat Sopoćko profesor, wychowawca i ojciec duchowy alumnów i kapłanów, Bialystok 2008.

4. Ciereszko H., Życie i działalność Księdza Michała Sopoćki (1888-1975). Petna biografia Apostota Miłosierdzia Bożego, Cracow 2006. 
5. Młyńska E., Ksiadz Michat Sopoćko jako wychowawca, "Katecheta" 2008, no. 11 , pgs. 67-71.

6. Olszewski M., Ksiadz Michat Sopoćko jako profesor wyktadowca w Wilnie Bl. Michael i w Białymstoku, "Rocznik Teologii Katolickiej", 2016, vol. XV/1, pgs. 181-200.

7. Skreczko A., Wychowanie chrześcijańskie w ujęciu Ks. Michała Sopoćki, "Rocznik Teologii Katolickiej” 2005, vol. IV, pgs. 59-98.

8. Sopoćko M., Autorytet $w$ rodzinie a wolność dziecka, "Ku szczytom," Vilnius 1939.

9. Sopoćko M., Cel, podmiot i przedmiot wychowania, Vilnius 1933.

10. Sopoćko M., Dziennik, Białystok 2012, Edition 2.

11. Sopoćko M., Mikołaj Łęczycki o wychowaniu duchowym, Vilnius 1935.

12. Sopoćko M., Mitosierdzie Boga w dzietach Jego, Paris 1967, Vol. 4.

13. Sopoćko M., Obowiazki względem Ojczyzny, Warsaw 1922.

14. Sopoćko M., O obowiazkach społecznych, Vilnius 1931.

15. Sopoćko M., Pedagogika, Vilnius 1933, typescript.

16. Sopoćko M., Polskie i katolickie ideaty i systemy wychowawcze, Poznan 1936.

17. Sopoćko M., Przyrodzone i nadprzyrodzone czynniki wychowania, Cracow 1937.

18. Sopoćko M., Rodzina w prawodawstwie na Ziemiach Polskich, Vilnius 1926.

19. Sopoćko M., Wspomnienia, "Wiadomości Kościelne Archidiecezji w Białymstoku" 13(1985) no. 3.

20. Sopoćko M., Wspomnienia z przeszłości (Życiorys napisany własnymi słowami), WKAB 13(1985) no. 2.

21. Steć D., Wychowawca, aby pociagat, musi być autentyczny, "Czas Miłosierdzia", 162(2003) no. 10.

22. Strzelecki S., Ksiądz Michat Sopoćko jakiego znatem i pamiętam, Warsaw 2004.

23. Strzelecki S., Wkład księdza Michała Sopoćki w formację duchowieństwa, Bialystok 1983. 